\title{
Effect of Oil Content on Biogas Production, Process Performance and Stability of Food Waste Anaerobic Digestion
}

\author{
Olumide Wesley Awe $\mathrm{Aw}^{1,2,3} \cdot$ Jiaxin $\mathrm{Lu}^{2} \cdot$ Shubiao $\mathrm{Wu}^{2} \cdot$ Yaqian $\mathrm{Zhao}^{1} \cdot \mathrm{Ange} \mathrm{Nzihou}^{3} \cdot \mathrm{Nathalie} \mathrm{Lyczko}^{3}$. \\ Doan Pham Minh ${ }^{3}$
}

\begin{abstract}
The primary cause of anaerobic digester failure includes accumulation of inhibitory substances and intermediate products such as volatile fatty acids (VFAs), free ammonia $\left(\mathrm{NH}_{3}{ }^{+}\right)$, and ammonium $\left(\mathrm{NH}_{4}{ }^{+}\right)$. They (except VFAs) are however required as essential nutrients for bacteria growth. The current study specifically investigated the effect of oil content on the biogas production and the stability of anaerobic digestion of food waste. Two lab scale reactors were designed with different organic loading rates and feeding adjustment of used oil addition to testing the effects of lipids on biodegradation and biogas production. The results indicate that, at $2.0 \mathrm{~g} \mathrm{VS} \mathrm{L}^{-1} \mathrm{~d}^{-1}$, the addition of oil $(5 \% \mathrm{v} / \mathrm{v})$, caused the reactor failure, whereas, at $4.0 \mathrm{~g} \mathrm{VS} \mathrm{L}^{-1} \mathrm{~d}^{-1}$, the reactor remained stable for 10 days before the accumulation of VFAs, which resulted in low $\mathrm{pH}$, and thus reduced the biogas and methane production. The addition of $\mathrm{NaOH}$ to reactivate the reactors can only improve $\mathrm{pH}$, alkalinity and negatively increased viscosity, but there was no significant effect on biogas production and VFAs concentration. An effective solution to reactivate the reactors was achieved by recirculating $50 \%$ of both reactor's effluent back to the reactors. This resulted in biogas recovery and stable process performance of the reactors. Surprisingly, $\mathrm{NH}_{4}{ }^{+}-\mathrm{N}_{\text {remained }}$ stable $\left(1400 \mathrm{mg} \mathrm{L}^{-1}\right)$ throughout the period, far less than the critical concentration of $3000 \mathrm{mg} \mathrm{L}^{-1}$. On the contrary, the low $\mathrm{NH}_{4}{ }^{+}-\mathrm{N}$ couldn't contribute to buffering the reactor's high VFA concentration during the unstable period, thereby raising new questions on its roles in anaerobic digestion process.
\end{abstract}

Keywords Biogas $\cdot$ Anaerobic co-digestion $\cdot$ Inhibition $\cdot \mathrm{NaOH}$ dosing $\cdot$ Food waste $\cdot$ Lipids

\section{Introduction}

It has been reported that more than 1.3 billion tons of food waste $(\mathrm{FW})$ are discarded every year, with about 100 million tonnes coming from Europe [1, 2] and about 60 million tons of FW from China, with Beijing alone generating 1600

Olumide Wesley Awe

wesley.awe@ucdconnect.ie

1 UCD Dooge Centre for Water Resources Research, School of Civil Engineering, University College Dublin, Newstead, Belfield, Dublin 4, Ireland

2 Key Laboratory for Clean Renewable Energy Utilization Technology of Ministry of Agriculture, College of Engineering, China Agricultural University, Beijing 100083, People's Republic of China

3 Université de Toulouse, Mines Albi, CNRS UMR 5302, Centre RAPSODEE, Campus Jarlard, 81013 Albi Cedex 09, France tons per day [3]. According to the Food and Agriculture Organisation of the United Nation (FAO) [1, 4], the FW and losses amount is roughly US\$ 680 billion in industrialized countries and over US\$ 310 billion in developing countries. This is also the amount indicating the resources waste in producing them, which include land, water, labour and capital, energy, and the unnecessary production and emission of greenhouse gases (GHGs), thereby contributing to global warming and climate changes $[1,5,6]$. According to a report of the Natural Resources Defense Council (NRDC) [7], in the USA alone, more than 36.4 million tons of FW was sent to landfills in 2012, costing US $\$ 165$ billion, and responsible for $16 \%$ of its methane emissions [5, 8].

FW can be divided into three broad categories; lipids, proteins, and carbohydrates, in which their biodegradability or hydrolysis rate differs from each other: lipids $<$ proteins $<$ carbohydrates $[9,10]$. That is why lipids degradation is seen as a rate-limiting step for FW anaerobic digestion (AD) [9]. Lipids in FW is a mixture of vegetable oils and 
animal fats. The production of vegetable oils and animal fats account for about 160 million tons per year worldwide, and about $80 \%$ of this is used for human consumption [10]. Chinese FW is different from other countries $[1,11]$, typically, rich in oil and salinity content, probably due to the dietary habit in China. They are characterized by the high amount of organic matter; lipids (22.8-31.5\%), protein (14.7-28.6\%), and carbohydrate dry matter (25.1-30.7\%) [5]. Due to the high organic carbon and protein content in FW coupled with the high lipid content of used oil waste, they can be collected and co-digested with either sewage sludge or animal manures for energy and resource recovery.

The lipids content in FW will affect the digestion process due to excessive production of long chain fatty acids (LCFAs). This has been proved to be toxic to anaerobic bacteria community $[2,12,13]$. The levels at which LCFAs become toxic vary widely, depending on acids forms, which are predominant in the digester. Also, the primary cause of $\mathrm{NH}_{3}$ production and accumulation in the digester is the degradation of FW and oil, as they are rich in protein [6, 14]. In the digester, $\mathrm{NH}_{3}$ and ammonium ions $\left(\mathrm{NH}_{4}{ }^{+}\right)$are always present, as they are used as essential nutrients for the bacteria growth. Therefore, $\mathrm{NH}_{4}{ }^{+}-\mathrm{N}$ can inhibit the activity of methanogens and hence reduce the biogas production when they are present at high concentration $\left(>3000 \mathrm{mg} \mathrm{L}^{-1}\right)[6$, 15]. $\mathrm{NH}_{3}$ was reported to be more inhibitory than $\mathrm{NH}_{4}{ }^{+}-\mathrm{N}$ due to its capacity to penetrate through the cell membranes $[16,17]$. There is, however, an uncertainty threshold at which $\mathrm{NH}_{3}$ concentration becomes inhibitive in the digesters. Interestingly, Moestedt et al. [16], reported that a mixture with a higher percentage of FW than sewage sludge may not likely have ammonia inhibition, due to the availability of higher carbon in the mixture.

Theoretically, lipids have the capacity to generate more methane than proteins and carbohydrates [18, 19]. Methane potential yield of lipids $\left(1000 \mathrm{~mL} \mathrm{~g}^{-1} \mathrm{VS}^{-1}\right)$, proteins $\left(480 \mathrm{~mL} \mathrm{~g}^{-1} \mathrm{VS}^{-1}\right)$ and carbohydrate $\left(373 \mathrm{~mL} \mathrm{~g}^{-1} \mathrm{VS}^{-1}\right)$ has been well reported [13, 20]. Alves et al. [21], concluded that despite its limitations, lipids are ideal substrate for methane production with biogas production of $1.425 \mathrm{~g} \mathrm{~L}^{-1}\left(\mathrm{CH}_{4}\right.$ of $69.5 \%$ ), compared to proteins $0.92 \mathrm{~g} \mathrm{~L}^{-1}\left(\mathrm{CH}_{4}\right.$ of $\left.68.8 \%\right)$, and carbohydrates $0.83 \mathrm{~g} \mathrm{~L}^{-1}\left(\mathrm{CH}_{4}\right.$ of $\left.50 \%\right)$. Once the VS content was $95-99 \%$, if thickened to $5 \%$, it can be suitable for the AD. But mono digestion of used oil is practically impossible because of high lipids concentration and production of LCFAs, which are known for inhibition of anaerobic microorganisms [1, 22-27]. The LCFAs produced are toxic to hydrogen-producing bacteria and acetotropic and hydrogenotrophic methanogenic and acetoclastic bacteria, even at low concentrations [1, 13, 20, 25, 28]. As a result, oil has been added by some researcher to enhance biogas production while problems were also reported. The LCFAs adsorption onto the biomass caused many operational challenges; digester foaming, flotation, biological bulking, odours, oxygen mass-transfer difficulties, increased effluent concentrations of organic matter, which may result in substrate and product transport limitation, clogging of gas collection and handling systems, blockage of pipes and pumps $[1,9,13$, 22, 23, 29-32]. Similarly, a high concentration of lipid can cause process instability through sludge flocculation (biomass wash out), direct inhibition, VFAs overload, and physical fouling of equipment [30, 33].

Many other researchers have focused on finding a solution to these operational challenges, such as anaerobic co-digestion of fat-rich matter with organic matter such as sewage sludge, farm manure, agricultural waste, organic fraction of municipal waste [4, 20, 34-36]. For examples, Gamble et al. [4] reported the design and modeling of the anaerobic codigestion process applied to municipal solid wastes and FW and claimed $\mathrm{FW}$ potential of $435\left(\mathrm{~mL} \mathrm{~g}^{-1} \mathrm{VS}^{-1}\right)$ on average $\mathrm{C} / \mathrm{N}$ of 14.8. Pastor et al. [20] worked on co-digestion of used oils and urban landfill leachates with sewage sludge and the effect on the biogas production and reported that used oil can be more suitable co-substrate for AD than landfill leachate due to better results of used oil in terms of biogas production, high solids concentration and low variability in its composition as compared with landfill leachate. Hendriksen and Ahring [34] worked on the effects of ammonia on growth and morphology of thermophilic hydrogen-oxidizing methanogenic bacteria and reported that ammonia had a pronounced effect on cell morphology, including the formation of large aggregates. Nielsen et al. [35] focused on the regulation and optimization of the biogas process using propionate as a key parameter. They reported that a more stable and efficient utilization of the substrate was observed when propionate was used as a process indication. In addition, Alibardi and Cossu [37] worked on composition variability of the organic fraction of municipal solid waste and effects on hydrogen and methane production potentials. They reported that the variability of the waste composition of OFMSW produced a marked effect on hydrogen potential production. Other studies have suggested the addition of adsorbent into the digesters, such as fibres and bentonite powder [33]. They also suggested the use of novel anaerobic flotation reactors, separation of oil prior to AD operation [13, 18, 22]. In such case, the hydraulic retention time (HRT) can be reduced by coupling of thermophilic and mesophilic reactors with $\mathrm{H}_{2}$ production prior to recirculation for $\mathrm{CH}_{4}$ production [38, 39], while Nielsen [40] compared two-stage thermophilic $\left(55^{\circ} \mathrm{C}\right)$ anaerobic digestion with one-stage thermophilic $\left(55^{\circ} \mathrm{C}\right)$ digestion of cattle manure.

Therefore, with the high amount of lipids in FW, it is necessary to seek some effective methods of eliminating the limitation for achieving high performance of FW AD. The full details of their effects on the process performance and stability are still not well understood despite many studies 
on this subject. However, the crucial issues are to investigate and determine the limit, where oil addition or oil content in FW does not inhibit the AD process. This study aims to investigate the effect of organic loading rates (OLR), alkalinity, total volatile fatty acids (tVFA), $\mathrm{pH}$ and $\mathrm{NH}_{4}{ }^{+}$on the biogas production and methane yield of an $\mathrm{AD}$ of $\mathrm{FW}$, and also to examine the effect of oil addition on the process performance and stability.

\section{Materials and Methods}

\section{Materials}

The used-oil and the FW used in this study were collected from the student's restaurants, China Agricultural University, Beijing. It was screened manually to remove impurities such as wastepaper, metal items, plastic, and large bones. The remaining waste was grounded in an electric blender with the addition of an equal water volume for dilution to obtain $12.8-15 \%$ wet weight of TS content. The homogenized FW was partly stored in a refrigerator at $4{ }^{\circ} \mathrm{C}$ for immediate use, while the rest was stored at $-10{ }^{\circ} \mathrm{C}$ for a long time use to prevent biological decomposition. Frozen $\mathrm{FWs}$ were thawed in a refrigerator at $4{ }^{\circ} \mathrm{C}, 24 \mathrm{~h}$ prior to use. The characteristics of the FW are summarised in Table 1.

The AD inoculum used in this study was initially collected from a large-scale biogas plant located in Shun Yi district, Beijing, China. It was previously used in a labscale anaerobic digestion that was operated and used for pig manure digestion, for 300 days, under mesophilic condition $\left(37 \pm 1{ }^{\circ} \mathrm{C}\right)$. The inoculum in the digester was incubated (kept running) at $37 \pm 1{ }^{\circ} \mathrm{C}$ to degas it and to ensure complete degradation of residual organic matter, while at the same time to remove the dissolved methane content. The characteristics of the inoculum are jointly shown in Table 1.

\section{The CSTR Experimental Design and Set Up}

Two laboratory-scale semi-continuous stirred-tank reactors (CSTRs) under mesophilic conditions with 15 and 10 litres of total and effective working volumes, respectively, were employed (Fig. 1). There were two ports on each reactor; with feeding and effluent discharge port set at the top and bottom of each reactor, respectively. The biogas was collected with $60 \mathrm{~L}$ gas bag and connected at the top of each reactor. The two reactors were stirred intermittently by a topmounted mechanical stirrer at $120 \mathrm{rpm}$ with $1 \mathrm{~h}$ on and $1 \mathrm{~h}$ off to ensure total mix. The mesophilic $\left(37 \pm 1^{\circ} \mathrm{C}\right)$ condition was maintained using temperature-controlled water baths $\left(\mathrm{LML}^{-1}\right)$. Two OLRs were set for the two reactors. The first reactor (R1) OLR was set at $2.0 \mathrm{~g} \mathrm{VS} \mathrm{L}^{-1} \mathrm{~d}^{-1}$ with $160 \mathrm{~g}$ of $\mathrm{FW}$, while the second reactor (R2) OLR was set at $4.0 \mathrm{~g} \mathrm{VS}$ $\mathrm{L}^{-1} \mathrm{~d}^{-1}$ with $320 \mathrm{~g}$ of $\mathrm{FW}$. Both reactors were maintained at 20 days' HRT. These were fed into the reactors once per day and approximate $500 \mathrm{~mL}$ of digestate was drawn out through the outlet port at the bottom of the each CSTR, manually per day and kept in a single container as mixed effluent. The experiment was divided into eight phases in order to investigate the effect of oil additions on various OLRs, biogas productions and methane yield, performance and stability of the entire process as well. Phase I (0-25 days), involved the addition of FW alone with the two mentioned OLRs. Phase II (25-29) involved addition of 5\% oil
Table 1 Characterisation of substrates used for anaerobic digestion in two parallel CSTRs

\begin{tabular}{|c|c|c|c|c|}
\hline Parameters & Inoculum (R1) & Inoculum (R2) & Food waste (FW) & $\mathrm{FW}+\mathrm{OIL}(\mathrm{R} 1 \& \mathrm{R} 2)$ \\
\hline $\mathrm{Ph}$ & $6.67 \pm 0.1$ & $7.25 \pm 0.07$ & $4.87 \pm 0.05$ & $4.55 \pm 0.24$ \\
\hline TS (\%) & $5.7 \pm 2.54$ & $5.3 \pm 1.73$ & $14.3 \pm 2.50$ & $18.50 \pm 0.41$ \\
\hline VS (\%) & $3.6 \pm 1.47$ & $2.4 \pm 0.71$ & $13.1 \pm 2.23$ & $17.57 \pm 0.44$ \\
\hline$\% \mathrm{VS}$ (of TS) & $64 \pm 6.67$ & $53.5 \pm 7.07$ & $91.90 \pm 1.06$ & $94.99 \pm 0.25$ \\
\hline Ash content (\%) & $33.71 \pm 0.24$ & $46.61 \pm 0.09$ & $8.20 \pm 0.02$ & $5.01 \pm 0.07$ \\
\hline $\mathrm{NH}_{4}^{+}-\mathrm{N}\left(\mathrm{mg} \mathrm{L}^{-1}\right)$ & 3805 & 651 & 166 & - \\
\hline $\operatorname{TCOD}\left(\mathrm{mg} \mathrm{L}^{-1}\right)$ & 12,750 & 21,860 & $154,250 \pm 27,170$ & $358,500 \pm 707$ \\
\hline SCODs $\left(\mathrm{mg} \mathrm{L}^{-1}\right)$ & 6,750 & 18,500 & $39,083 \pm 33,276$ & $96,875 \pm 177$ \\
\hline SCOD/TCOD & 0.53 & 0.85 & 0.25 & 0.27 \\
\hline $\mathrm{C}(\%)$ & $21.50 \pm 0.18$ & $29.74 \pm 0.19$ & $51.12 \pm 1.01$ & $57.02 \pm 0.2$ \\
\hline $\mathrm{N}(\%)$ & $9.52 \pm 0.12$ & $2.79 \pm 0.03$ & $2.74 \pm 0.07$ & $2.63 \pm 0.12$ \\
\hline $\mathrm{O}(\%)$ & $29.08 \pm 0.02$ & $16.08 \pm 0.01$ & $30.41 \pm 0.04$ & $23.84 \pm 0.04$ \\
\hline $\mathrm{H}(\%)$ & $4.87 \pm 0.08$ & $3.93 \pm 0.03$ & $7.2 \pm 0.25$ & $7.84 \pm 0.02$ \\
\hline $\mathrm{S}(\%)$ & $1.33 \pm 0.12$ & $0.77 \pm 0.01$ & $0.52 \pm 0.07$ & $0.66 \pm 0.03$ \\
\hline $\mathrm{C} / \mathrm{N}$ & $2.26 \pm 0.01$ & $10.66 \pm 0.03$ & $18.68 \pm 0.11$ & $21.68 \pm 0.22$ \\
\hline Carbohydrate (g-glucose $\mathrm{L}^{-1}$ ) & nd & nd & $26.51 \pm 0.3$ & $33.21 \pm 0.09$ \\
\hline Lipids $\left(\mathrm{g} \mathrm{L}^{-1}\right)$ & nd & nd & $51.1 \pm 0.85$ & $98.25 \pm 4.31$ \\
\hline
\end{tabular}




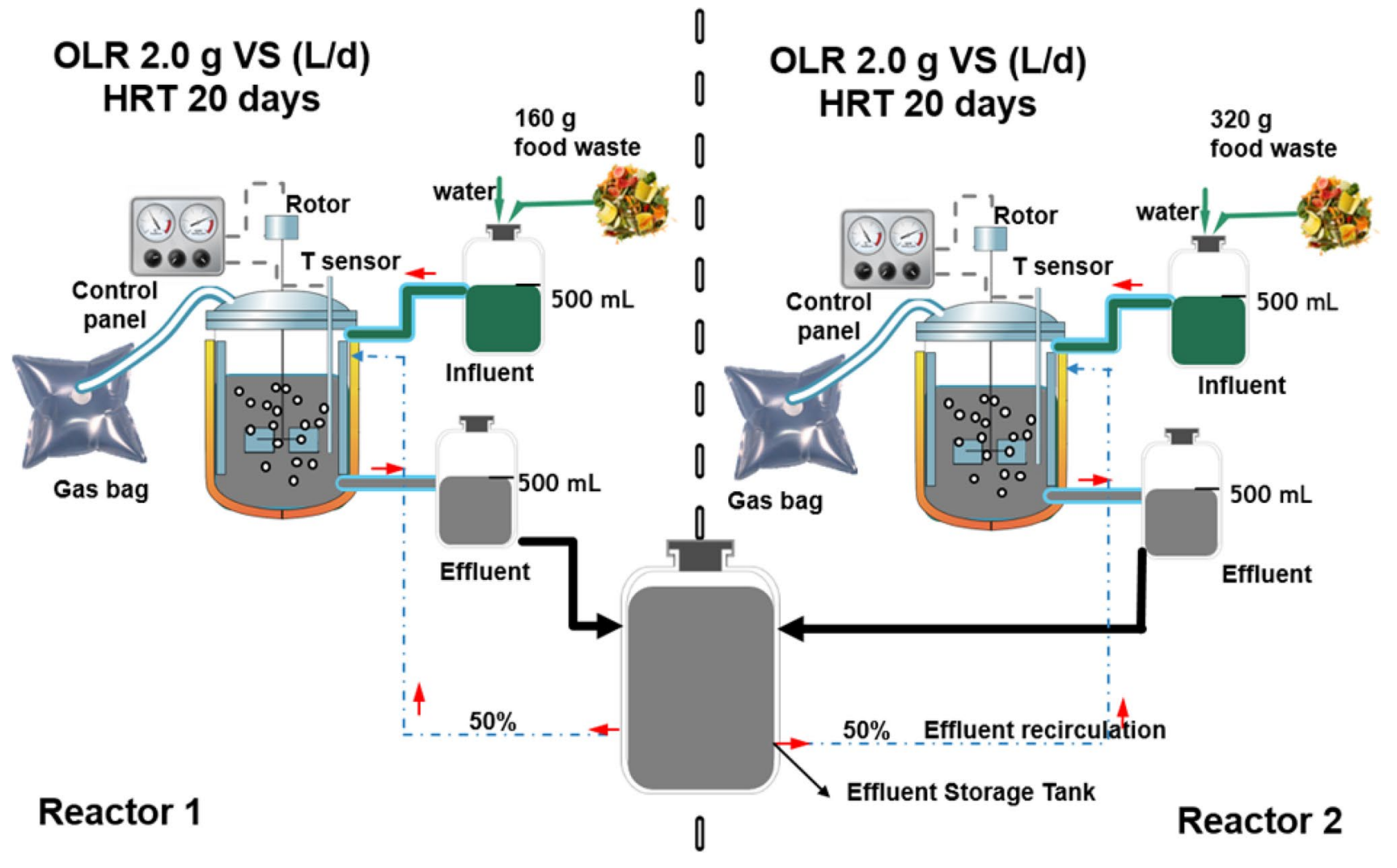

Fig. 1 Flow diagram of laboratory-scale setup for AD of food waste with effluent tank for recirculation

content based on OLRs. Phase III (29-30) oil addition was stopped, phase IV (30-40), reactor R1 OLR was changed to $4.0 \mathrm{~g} \mathrm{VS} \mathrm{L}^{-1} \mathrm{~d}^{-1}$, phase V (40-57) $5 \%$ oil content was added again. Phase VI (57-63) $\mathrm{NaOH}$ was added due to lower the $\mathrm{pH}$ and LCFA accumulation. Phase VII (63-68), feeding was stopped on both reactors for 5 days. Phase VIII (68-90), 50\% recirculation of effluent was conducted, and biogas production restarted and continued to the end. The experiment ran for 90 days, and the residual digestate was analyzed daily for $\mathrm{pH}, \mathrm{VS}, \mathrm{TS}, \mathrm{tVFA}$, alkalinity or total inorganic carbon (TIC), $\mathrm{NH}_{4}{ }^{+}-\mathrm{N}$, soluble chemical oxygen demand (SCOD), total chemical oxygen demand (TCOD), as well as daily biogas production and methane yields.

\section{Analytical Methods and Calculations}

The VS, TS, and $\mathrm{NH}_{4}{ }^{+}-\mathrm{N}$ were determined following the standard methods of the American Public Health Association [41]. The $\mathrm{pH}$ was determined using a digital $\mathrm{pH}$ meter (FE20, METTLER TOLEDO, Switzerland) coupled with a glass electrode (LE438, METTLER TOLEDO, Switzerland). To obtain the soluble fraction of the sample material, it was centrifuged (10,000 rpm for $15 \mathrm{~min}$ ), and the supernatant filtered through $0.45 \mu \mathrm{m}$ cellulose acetate membrane. Part of the filtered samples was used to determine the $\mathrm{NH}_{4}{ }^{+}-\mathrm{N}$ concentration, using a spectrophotometer (UV-1100, MAPADA Instrument). The SCOD and TCOD were determined using a HATCH DR/2800 spectrometer (Hatch Company, USA) following the standard methods in APHA, 2005. The tVFA, total alkalinity or TIC content were analyzed using Nordmann-titration method with $0.1 \mathrm{~N} \mathrm{H}_{2} \mathrm{SO}_{4}$ to endpoints of $\mathrm{pH} 5.0$ and 4.4 [11, 25, 27]. The sample was centrifuged ( $10,000 \mathrm{rpm}$ for $15 \mathrm{~min})$, diluted four times with deionized water and, $20 \mathrm{~mL}$ part of it was titrated, according to [9]. The tVFA/TIC (called FOS/TAC in Germany), as a digestion monitoring information were also determined. The values of TIC and tVFA were calculated using Nordmann [42] empirical Eqs. (1) and (2):

tVFA or FOS $\left(\mathrm{mg} \mathrm{L}^{-1}\right)=\left(\frac{20}{A} \times B \times 1.66-0.15\right) \times 500$

TIC or TAC $\left(\mathrm{mg} \mathrm{CaCO}_{3} \mathrm{~L}^{-1}\right)=\left(\frac{20}{A}\right) \times C \times 250$

where $\mathrm{A}$ is the volume of centrifuged sample used $(\mathrm{mL}), \mathrm{B}$ is the volume of acid $\left(0.1 \mathrm{~N} \mathrm{H}_{2} \mathrm{SO}_{4}\right)$ used to go from $\mathrm{pH} 5$ to $\mathrm{pH} 4.4(\mathrm{~mL})$, and $\mathrm{C}$ is the volume of acid $\left(0.1 \mathrm{~N} \mathrm{H}_{2} \mathrm{SO}_{4}\right)$ used to go from start to $\mathrm{pH} 5.5(\mathrm{~mL})$. 
The two reactors inoculum samples, FW sample with and without oil addition were oven-dried $\left(105^{\circ} \mathrm{C}\right)$ and used for ash content, ultimate analysis to determine carbon (C), nitrogen $(\mathrm{N})$, sulphur $(\mathrm{S})$ and hydrogen $(\mathrm{H})$ content by elemental analyser (Vario EL/microcube, Germany). The value of ash content and oxygen $\left(\mathrm{O}_{2}\right)$ were calculated using Eqs. (3) and (4) as follows:

$\operatorname{Ash}(\%)=\frac{M_{a s h}-M_{c o n t}}{M_{o d}-M_{c o n t}} \times 100$

where Ash (\%) is the mass percent of ash, based on $105^{\circ} \mathrm{C}$ oven-dried mass of sample, $\mathbf{M}_{\text {ash }}$ is the mass of ash and container $(\mathrm{g}), \mathrm{M}_{\text {cont }}$ is the tare mass of container $(\mathrm{g})$, and $\mathrm{M}_{\mathrm{od}}$ is the initial mass of $105^{\circ} \mathrm{C}$ dried sample and container $(\mathrm{g})$.

Oxygen $\left(\mathrm{O}_{2}\right) \%=(100-(C+N+S+H+A s h))$

The daily biogas production volume was measured with a wet-type precision gas meter (LML ${ }^{-1}$, Changchun, China). The measured wet biogas and methane volumes were normalized and adjusted to the volumes at standard temperature (213.15 K) and pressure (101.325 kPa). The biogas composition was analyzed by using BIOGAS 5000 portable biogas analyzer (Geotechnical Instruments UK Ltd). The gas analyser was calibrated using certified gas, $\mathrm{CH}_{4}(5,5$, $60 \%), \mathrm{CO}_{2}(5,10,40 \%)$ and, $\mathrm{O}_{2}(6,0,0 \%)$. The biogas and methane yields were calculated by dividing the daily gas yield (normalized), by the daily VS added to the reactors.

The OLR was determined using Eq. (5):

$\mathrm{OLR}=\frac{M \times T S \times V S}{V}$

where $\mathrm{M}$ is the total mass input flow in grams, TS and VS are percentages based on substrate and the $\mathrm{V}$ is the volume of the reactors in litres $(\mathrm{L})$.

\section{Results and Discussion}

\section{Initial Effects of Oil Added to Both Reactors}

Figures 2 and 3 a show the biogas yield and methane yield $\mathrm{mL} \mathrm{g} \mathrm{VS}^{-1}$ day $^{-1}$ The two reactors were operated at $2.0 \mathrm{~g}$ VS L ${ }^{-1}$ day $^{-1}$ for R1, and $4.0 \mathrm{~g} \mathrm{VS} \mathrm{L}^{-1}$ day $^{-1}$ for R2 with stable operations for 25 days (phase I), after which oil content of $(5 \% \mathrm{v} / \mathrm{v})$, based on OLRs was added to the FW and fed to both reactors. Expectedly, TCOD of the mixtures increased to $295,250 \mathrm{mg} \mathrm{L}^{-1}$ for $\mathrm{R} 1$ and $304,000 \mathrm{mg} \mathrm{L}^{-1}$ for R2, respectively. After two days of operation (phase II), there was an acidification of R1 as a result of the oil additions, due to high lipid concentrations and accumulation of LCFAs. pH dropped in R1 from 6.9 to 6.1. Once the R2 was still operated well with increased biogas production. This indicated that R1 was probably overloaded or there might be
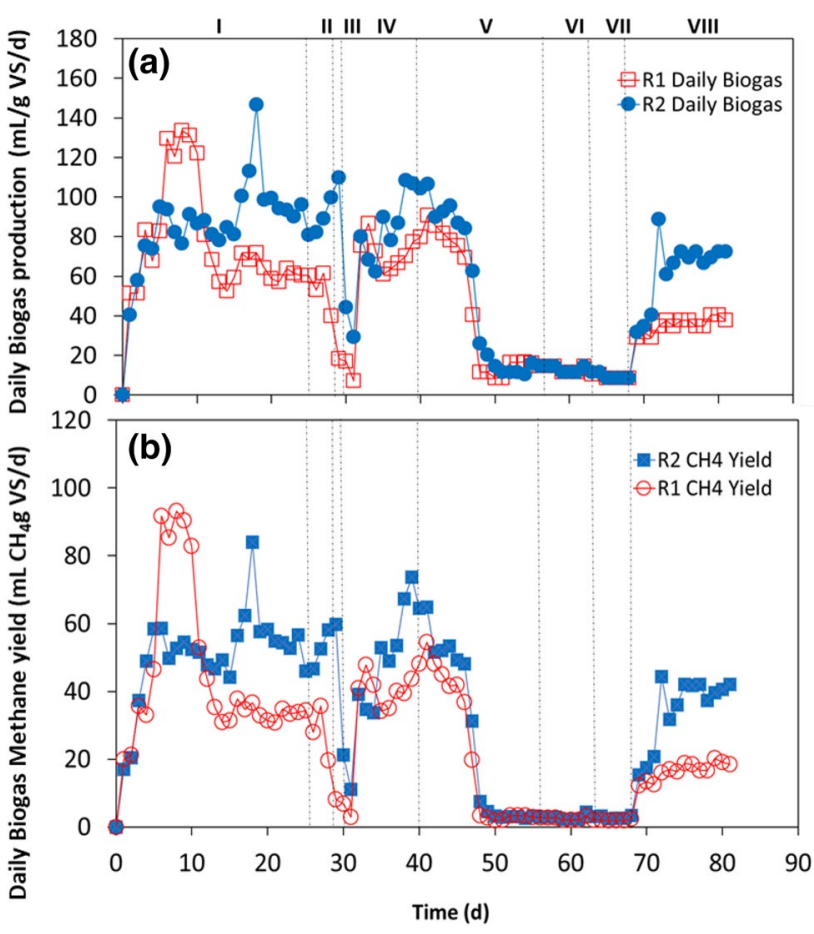

Fig. 2 Dynamic changes of a daily biogas production $\left(\mathrm{mL} \mathrm{g}^{-1}\right.$ VS day $\left.{ }^{-1}\right)$, and b daily methane yield $\left(\mathrm{mL} \mathrm{CH}_{4} \mathrm{~g} \mathrm{VS} \mathrm{day}^{-1}\right)$ in the process of $\mathrm{FW}$ AD under mesophilic condition

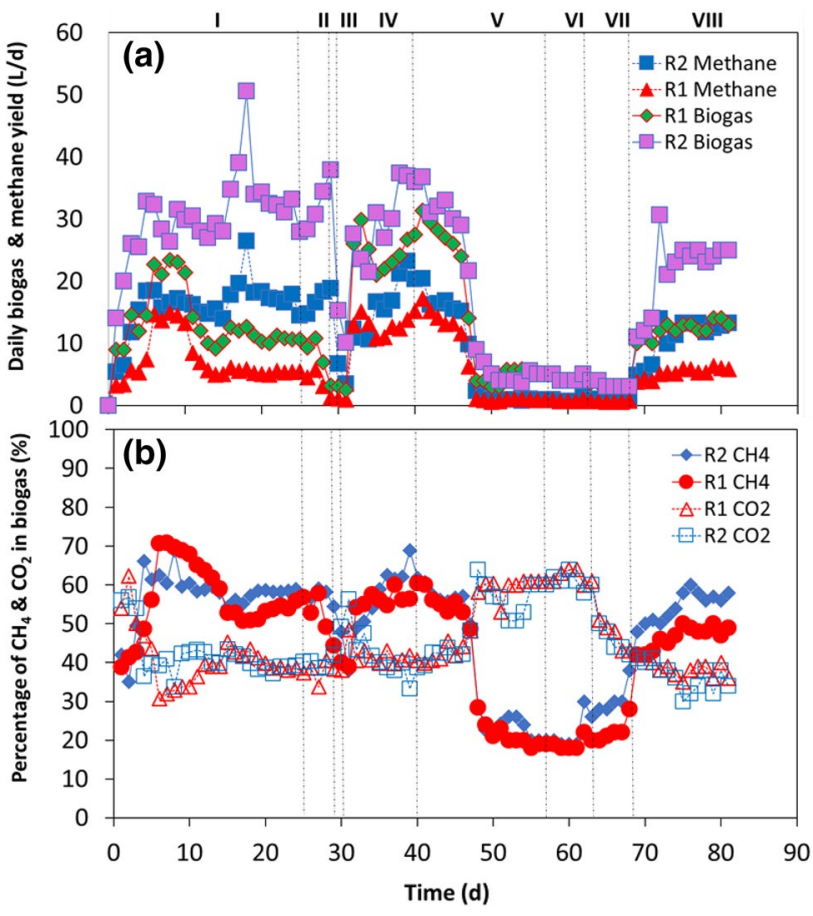

Fig. 3 Dynamic changes of a daily biogas production and methane yield $\left(\mathrm{L} \mathrm{day}^{-1}\right)$ of the two-reactor's combined, and b daily $\mathrm{CH}_{4}$ and $\mathrm{CO}_{2}$ composition (\%), in the process of $\mathrm{FW} \mathrm{AD}$ under mesophilic condition 
other underlining factors been responsible for R1 failures, as discussed below. Figure $3 \mathrm{~b}$ shows the biogas and methane compositions of R1 and R2. In phase I, the stable operation of both reactors was evidenced until the oil $(5 \% \mathrm{v} / \mathrm{v})$ was added to the reactors, which led to the initial failure of R1. The recovery was also shown (Figs. 2, 3) when oil addition was stopped and were operated at the same $4.0 \mathrm{~g} \mathrm{VS} \mathrm{L}^{-1}$ day $^{-1}$.

First, on the issue of overloading, the only notable changes in $\mathrm{R} 2$ was the slight reduction in average biogas production from 30.3 to $24 \mathrm{~L}^{-1}$ day $^{-1}(20.79 \%)$, while that of R1 was reduced from average 14.5 to $6.2 \mathrm{~L}^{-1}$ day $^{-1}(57.24 \%)$. The methane content of both reactors was from 56.9 to 44.4 and 56.8 to $54.45 \%$ for R1 and R2, respectively. The average $\mathrm{pH}$ in $\mathrm{R} 1$ reactor continues to drop (6.9-6.1) with increasing average VFA concentration from 696 to $2688 \mathrm{mg} \mathrm{L}^{-1}$ (74.10\%), while the alkalinity also declined from 2500 to $1750 \mathrm{mg} \mathrm{CaCO}_{3} \mathrm{~L}^{-1}$ (30\%). On the other hands, the average $\mathrm{pH}$ remained stable for $\mathrm{R} 2$ at 7.5 from 7.6, the VFA concentration average increased slightly from 1028 to $1194 \mathrm{mg} \mathrm{L}^{-1}$ $(13.9 \%)$, while the buffering capacity (alkalinity) increased from 729 to $4350 \mathrm{mg} \mathrm{CaCO} \mathrm{L}^{-1}$ (83.2\%), respectively, before and after when oil was added. Lastly, the average VFA/TIC ratio increased from 0.5 to 2.0 for $\mathrm{R} 1$, while the average VFA/TIC ratio for R2 slightly increased from 0.4 to 0.43 within the same period. VFA/TIC values between 0.3 and 0.5 are typically indicators of stable anaerobic digestions [43, 44], while Lossie et al. [45] argued that the ratio between 0.2 and 0.6 implied stable process without the risk of acidification.

Secondly, an alternative possibility for this failure might be that the differences in microbial communities of the two reactors might also be a contributing factor (see Table 1). This is because different microbial community reacts differently to changes in their feeding substrates. The addition of $5 \% \mathrm{v} / \mathrm{v}$ of oil probably led to changes in the microbial community structure, which often affect their dynamics and abundance as suggested by Ferguson et al. [46] and Yi et al. [47], which ultimately led to decrease in biogas production and the reactor failure. The destabilizations of the microbial community can lead to the limited substrate and product transport. According to Zhang et al. [11, 48], damage cells and reduced activities of microbial communities may have been stressed. Biomass floatation and biomass washout were observed with R1 effluent, with TCOD increased from $22,250 \mathrm{mg} \mathrm{L}^{-1}$ before the oil addition to $79,400 \mathrm{mg}$ $\mathrm{L}^{-1}(71.66 \%)$, while that of $\mathrm{R} 2$ remained relatively stable at $37,600 \mathrm{mg} \mathrm{L}^{-1}$ from $35,500 \mathrm{mg} \mathrm{L}^{-1}$ before, oil was added as shown in Fig. 4.

The decreased in biogas production was an indication of inhibition of the methanogenesis due to the toxic effect of accumulated compounds. According to Angelidaki and Ahring [49], neutral fats are easily hydrolyzed to LCFA,
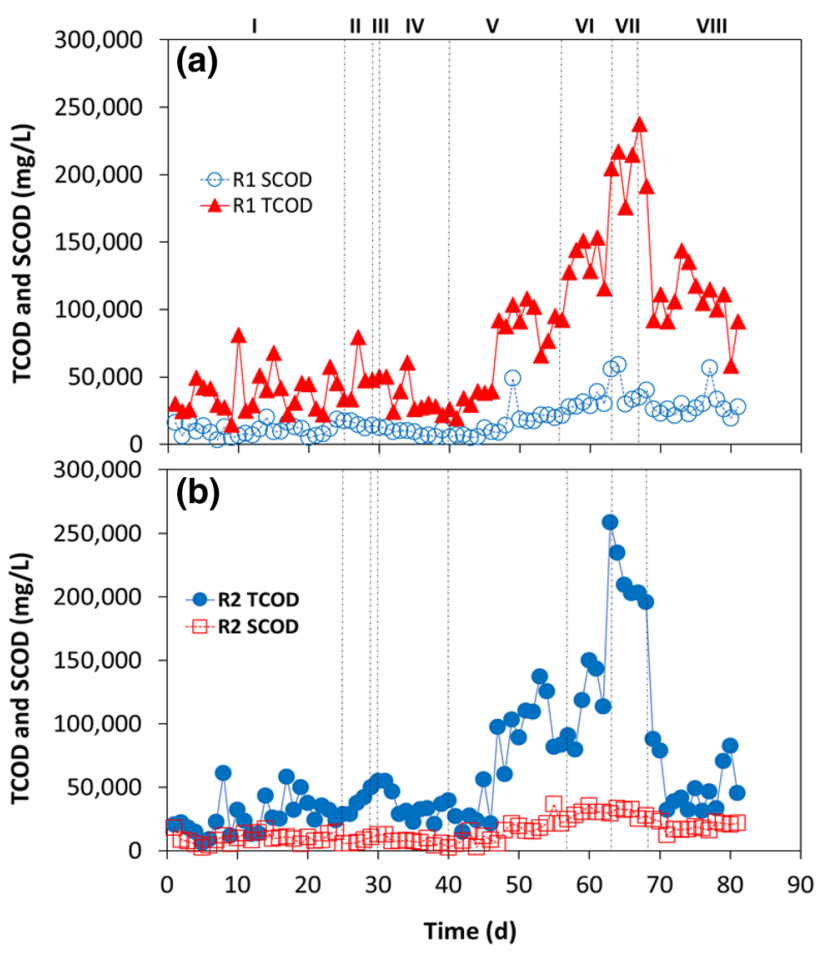

Fig. 4 Dynamic changes of a R1 SCOD and TCOD, and b R2 SCOD and TCOD, in the process of FW AD under mesophilic condition

which exert an acute toxic effect on the microorganisms, in which the $\beta$-oxidation and methanogenic pathways were involved. The toxicity mechanism is usually through adsorption onto cell wall, which will affect its transport and protective functions and probably lead to biomass flotation and biomass washout as reported above.

Additionally, part of this is also caused by rapid VFAs accumulation during hydrolysis, due to the higher growth rate of acidogens as compared to methanogens during the process as reported by Palatsi et al. [37]. It is understood that the acid-consuming methanogenic archaea are extremely sensitive and expectedly inhibited by an acid accumulation and decreasing $\mathrm{pH}$ than the acid-producing species [38, 39]. Lastly, VFA concentration in the range of 1000-3000 $\mathrm{mg} \mathrm{L}^{-1}$ would cause moderate inhibition [40]. In the present study, VFAs concentrations were in the range of $1028-2688 \mathrm{mg} \mathrm{L}^{-1}$. Also, the reduction in the $\mathrm{pH}$ affected lowering values of alkalinity which declined from 2500 to $1750 \mathrm{mg} \mathrm{CaCO}_{3} \mathrm{~L}^{-1}$ (30\%), thereby contributed to low methane production.

\section{Effects of First Changes on the Reactors}

In Phase III, to rescue the R1, firstly oil addition to both R1 and R2 was stopped. Secondly, the OLR of R2 was increased from 2.0 to $4.0 \mathrm{~g} \mathrm{VS} \mathrm{L}^{-1}$ day $^{-1}$ since it was apparently clear from $\mathrm{R} 1$ that at $2.0 \mathrm{~g} \mathrm{VS} \mathrm{L}^{-1}$ day $^{-1}, \mathrm{R} 1$ could not sustained 
the $5 \%$ oil addition. Thirdly, effluent recirculation from the combined effluent storage tank was applied to reactivate and recover the reactors. About $40 \%$ effluent was withdrawn from R1 and 20\% withdrawn from R2. In phase IV, after the recovery, the $\mathrm{pH}$ immediately increased and stabilised at 7.3 for both reactors and biogas production significantly increased in reactor $\mathrm{R} 1$ from 2.3 to $23.7 \mathrm{~L}^{-1}$ day $^{-1}(90.30 \%)$ and in reactor $\mathrm{R} 2$ from 10 to $25.2 \mathrm{~L}^{-1}$ day $^{-1}$ (63.49\%). This was clearly shown in Figs. 2 and 3.

\section{Effects of Oil Addition on the Process Performance and Stability of the Reactors}

After further 8 days of stable operation with stable reactors, and after initial 15 days' downtime and recovery, FW was processed and analyzed for all the parameters including lipid test to ascertain the amount of lipid present in the FW before the addition of $5 \%$ oil based on the reactor's OLRs. This ran successfully for the first 8 days (day 47th), with the values of TCOD and SCOD increased substantially due to the oil addition of 5\% (v/v) for both reactors as shown in Fig. 4. Also, the TCOD conversion efficiency peaking at $95 \%$ for R 1 and 94\% for R2 (Fig. 5c). The biogas production also increased, peaking at $28.6 \mathrm{~L}^{-1} \mathrm{day}^{-1}$ for $\mathrm{R} 1$, and $33.6 \mathrm{~L}^{-1}$ day $^{-1}$ for $\mathrm{R} 2$ (Fig. 3a). The peak $\mathrm{CH}_{4}$ content for $\mathrm{R} 1$ was $60 \%$ as shown in Fig. 3b, which yield $17.15 \mathrm{~L}^{-1}$ day $^{-1}$, while the $\mathrm{R}_{2} \mathrm{CH}_{4}$ content was $61 \%$, yielding $20.43 \mathrm{~L}^{-1}$ day $^{-1}$. Other parameters

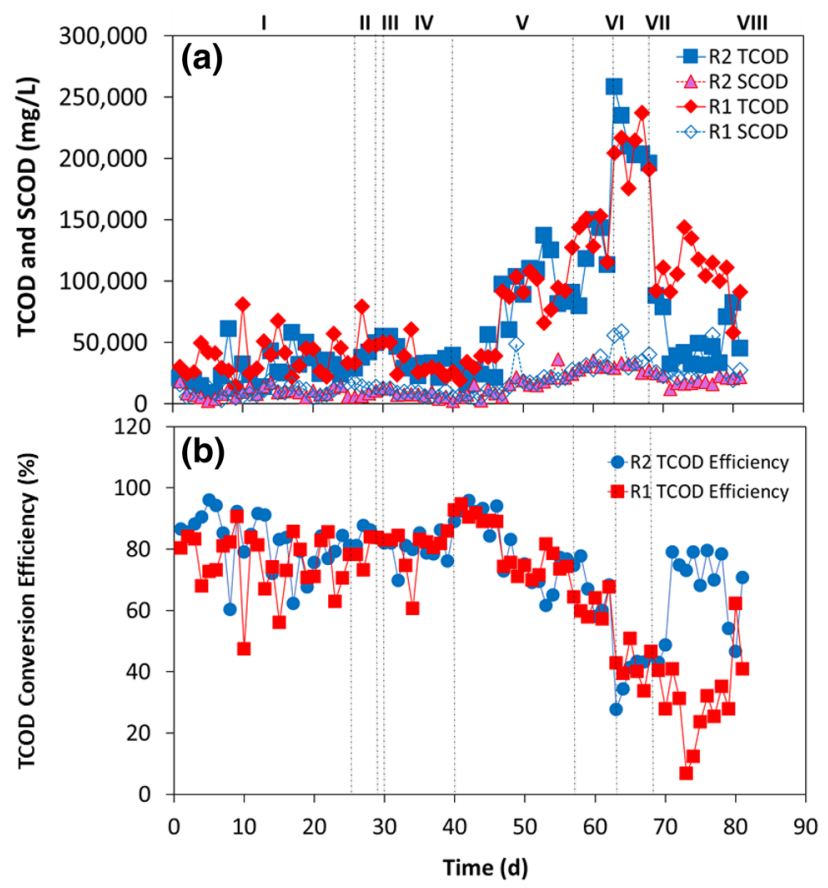

Fig. 5 Dynamic changes of a TSCOD and SCOD of the two-reactor's combined, and $\mathbf{b}$ TCOD removal efficiency for reactors R1 and R2, in the process of $\mathrm{FW} \mathrm{AD} \mathrm{under} \mathrm{mesophilic} \mathrm{condition}$ analyzed (tVFAs, TIC, FOS/TAC, $\mathrm{NH}_{4}{ }^{+}-\mathrm{N}, \mathrm{VS}$ and TS), shows clear stable reactor operations.

\section{Effects of Oil Addition on SCOD, TCOD, TCOD Conversion Efficiency and Effluent Quality}

The values of TCOD and SCOD increased immediately oil was added as expected. These were clearly shown in Fig. 4. Thereafter, after the 9th day after oil was added, the $\mathrm{pH}$ started to reduce (R1 from 7.2 to 6.3 and $\mathrm{R} 2$ from 7.4 to 6.9). However, feeding continue without oil addition to see how far this effect will go, until the $\mathrm{pH}$ finally reached 5.1 for R1 and 5.2 for R2, with TCOD conversion efficiency (Fig. 5b) reduced to $17 \%$ for $\mathrm{R} 1$ and $41 \%$ for $\mathrm{R} 2$, and biogas production reduced significantly to $3.7 \mathrm{~L}^{-1}$ day $^{-1}$ for both reactors. This represents a biogas reduction of 87.06 and $88.99 \%$ for R1 and R2, respectively. There was noticeable effluent colour changing from deep black to brownish colour with lipids formations and foaming. This might be due to the inability of the microorganisms to utilize the fed substrate, as a result of the inhibitions posed by the LCFAs accumulation in the reactor which has become toxic for the microorganisms. All these negative effects have led to the increase in odour level of the effluent.

\section{Effects of Oil Addition on pH, tVFAs, TIC and FOS/TAC}

Figures 6 and 7 show the dynamisms AD of FW without and with oil addition. It can be seen that, tVFAs increased
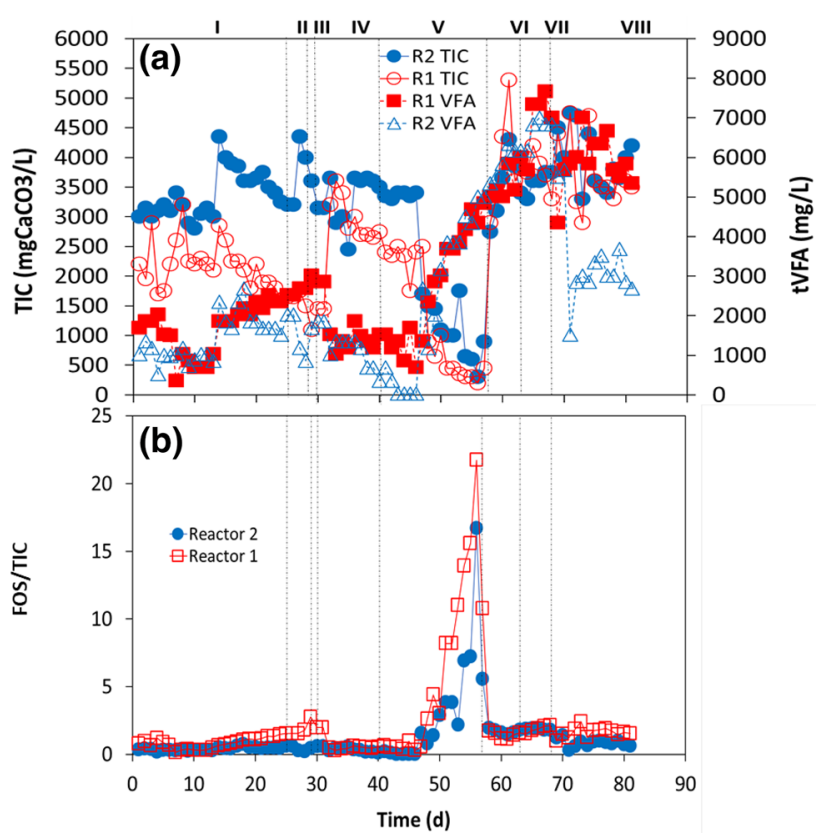

Fig. 6 Dynamic changes of a alkalinity (TIC) and tVFA of the tworeactor's combined, and $\mathbf{b} \mathrm{FOS} / \mathrm{TAC}$ ratio in the process of FW AD under mesophilic condition 


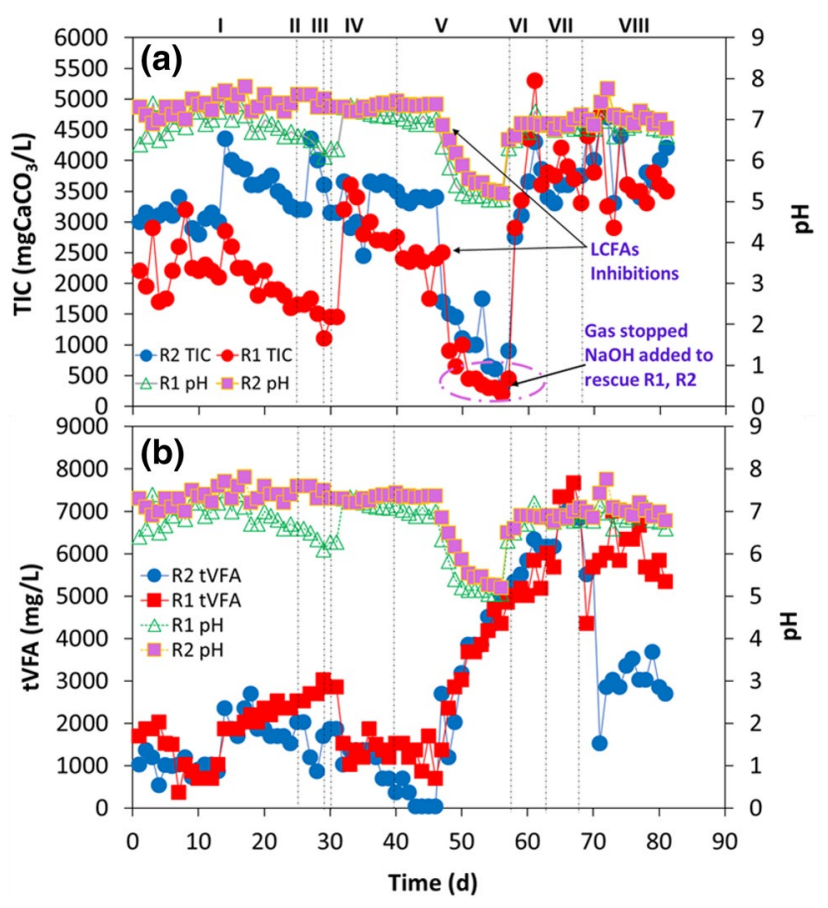

Fig. 7 Dynamic changes of a alkalinity (TIC) with PH, b tVFA with $\mathrm{PH}$, in the process of FW AD under mesophilic condition

significantly for $\mathrm{R} 1$ from the initial $1526 \mathrm{mg} \mathrm{L}^{-1}$ when oil was added and FOS/TAC ratio of 0.55 , to $4846 \mathrm{mg} \mathrm{L}^{-1}$ and FOS/TAC ratio of 10.77 , while $\mathrm{R} 2$ increased astronomically from initial $364 \mathrm{mg} \mathrm{L}^{-1}$ when oil was added and FOS/TAC ratio of 0.10 , to $5012 \mathrm{mg} \mathrm{L}^{-1}$ and FOS/TAC ratio of 10.77 .

The changes are clearly shown in Fig. 6b. This represents an increase of $1526-4846 \mathrm{mg} \mathrm{L}^{-1}(68.51 \%)$ and 364-5012 $\mathrm{mg} \mathrm{L}^{-1}$ (92.73\%) for reactors R1 and R2, respectively, which led to both reactor failures. The role of VFAs has been established and as a result, any variations in VFA concentrations indicate a kinetic separation between the acid producer (acidogens) and consumers (methanogenic archaea) microorganisms. Hence, VFA/TIC is normally used to measure and evaluate AD system stability. The ratio between 0.2 and 0.6 implied stable process without the risk of acidification [45]. It has been shown by Raposo [43] that a drop in $\mathrm{pH}$ leads to increase in VFA/TIC ratio $(>0.4)$ as a result of high VFA concentrations. This increase in VFAs concentration lowers the $\mathrm{pH}$ to a toxic level for some of the bacteria involved in the $\mathrm{AD}$, especially methanogenic bacteria that usually operate between 6.8 and 7.4. The $\mathrm{pH}$ in this case declined from 7.2 to 5.8 for R1 and from 7.4 to 6.5 for R2. This inhibition by high VFAs concentration was probably due to the adsorption to the surface of microorganisms, thereby limiting their nutrients transport ability to their cells, and led to $\mathrm{pH}$ reduction as well. Thus, the failure of the reactors is in agreement with findings of Raposo et al. [43] and Borja et al. [44] who reported that the operation of
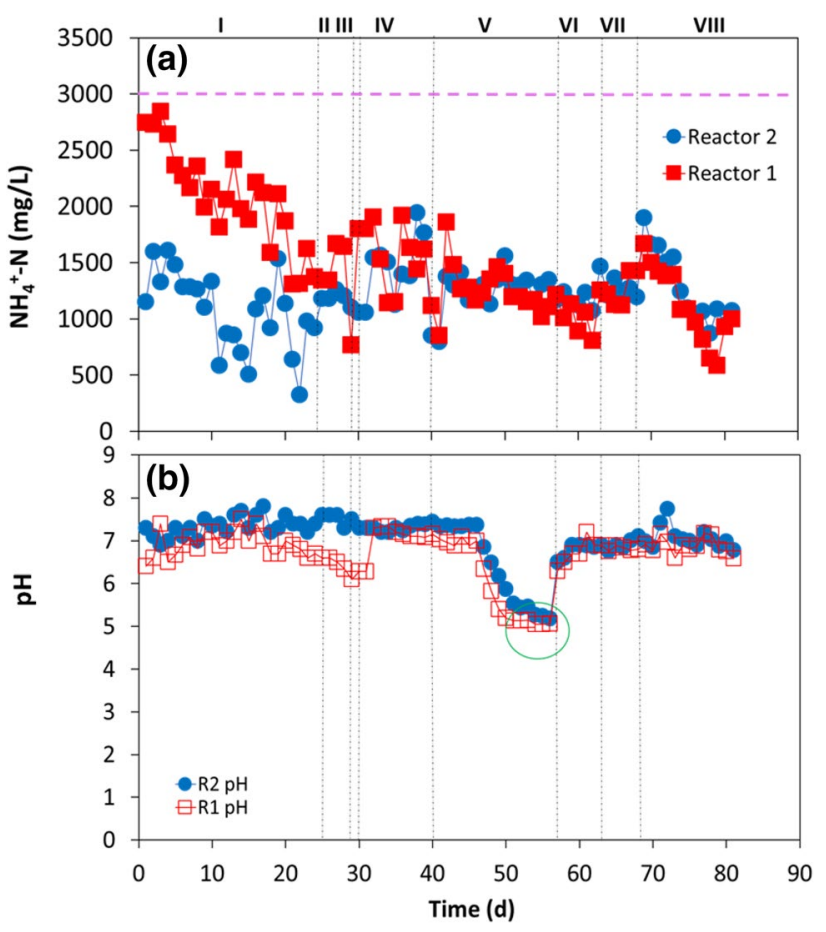

Fig. 8 Dynamic changes of a ammonia nitrogen $\left(\mathrm{NH}_{4}^{+}-\mathrm{N}\right)$, and $\mathbf{b}$ $\mathrm{pH}$, in the process of FW AD under mesophilic condition

the AD will cease to be stable, at a higher FOS/TAC ratio above $>0.5$. On the other hand, the alkalinity of the reactors significantly reduced, by $92.73 \%$ for R1 at the initial $2750 \mathrm{mg} \mathrm{L}^{-1} \mathrm{CaCO}_{3}$ when oil was added to $200 \mathrm{mg} \mathrm{L}^{-1}$ $\mathrm{CaCO}_{3}$, while for $\mathrm{R} 2$, it reduced by $91.43 \%$, from the initial $3500 \mathrm{mg} \mathrm{L}^{-1} \mathrm{CaCO}_{3}$ when oil was added to $300 \mathrm{mg} \mathrm{L}^{-1}$ $\mathrm{CaCO}_{3}$, as shown in Fig. 7a.

On the other hand, Fig. 6 a shows the combined effects of alkalinity (TIC) and tVFA on the two reactors. From Fig. 7a, $\mathrm{b}$, there is a corresponding effect of high VFA concentration and low TIC concentration on the reduction of the $\mathrm{pH}$ values (Fig. 8b), which definitely have negative effects on the activities of methanogenesis. This persisted in phase (V) up to phase (VII), despite the addition of $\mathrm{NaOH}$ to increase the buffering capacity (alkalinity) and the $\mathrm{pH}$.

\section{Effects of Oil Addition on $\mathrm{NH}_{4}{ }^{+}-\mathrm{N}$, TS Reduction, VS Conversion Efficiency and $\mathrm{pH}$}

Figure 8a shows the effects of oil addition on $\mathrm{NH}_{4}{ }^{+}-\mathrm{N}$ and surprisingly $\mathrm{NH}_{4}{ }^{+}-\mathrm{N}$ has been relatively stable even after the addition of $5 \%$ oil contents to the reactors, with $\mathrm{NH}_{4}{ }^{+}-\mathrm{N}$ ranging between 805 to $1404 \mathrm{mg} \mathrm{L}^{-1}$ for $\mathrm{R} 1$, and 797 to $1558 \mathrm{mg} \mathrm{L}^{-1}$ for R2. This is despite the reported protein content (14.7-28.6\%) of Chinese FW [5] and source of nitrogen in FW. This was because high protein contents are usually responsible for $\mathrm{NH}_{4}{ }^{+}-\mathrm{N}$ inhibition in digesters 
and also, contrary to previous result of Bank et al. [50], who worked on AD performance assessment of source-segregated domestic FW by mass and energy balance. Despite no $\mathrm{NH}_{4}{ }^{+}-\mathrm{N}$ inhibition, the system still failed, without biogas production. Clearly, there is a need for more investigation on the role of free ammonia or ammonium on process performance and stability of AD when there are high VFA concentration in the digester. It has already been established that ammonia plays a significant role in carbon to nitrogen $(\mathrm{C} / \mathrm{N})$ ratio balancing. In this study, the analysed $\mathrm{C} / \mathrm{N}$ for $\mathrm{FW}$ alone was 18.68 and for $\mathrm{FW}$ with $5 \%$ oil additions, it was 21.68 , which was in agreement with the previous studies in the literature [1, 5, 38].

Some researchers have suggested that ammonia can also buffer or neutralised the VFAs during the AD process, thereby stabilising the system and avoiding AD failure [1, $6,48,51]$. As shown in Fig. 8a, the tolerable or critical ammonium concentration for methanogenic microorganisms to stop growing or react negatively is $3000 \mathrm{mg} \mathrm{L}^{-1}$. In this study, $\mathrm{NH}_{4}{ }^{+}-\mathrm{N}$ concentration fell in the range of 770-2748 $\mathrm{mg} \mathrm{L}^{-1}$ for $\mathrm{R} 1$, and $325-1600 \mathrm{mg} \mathrm{L}^{-1}$ for R2, which is lower than the critical $\mathrm{NH}_{4}{ }^{+}-\mathrm{N}$ concentration. This is similar to the work of Zhang et al. [1] with range of 476.9-1645 $\mathrm{mg} \mathrm{L}^{-1}$. Despite this, the biogas production continued reducing significantly toward the end of phase (V), and up to early part of phase (VIII). This result is not in agreement with the findings of Bank et al. [50], who reported a higher ammonia concentration of more than $5000 \mathrm{mg} \mathrm{L}^{-1}$ during the similar semi-continuous AD of FW. The R1 TS reduction efficiency stood at $83 \%$ after the oil was added, but later reduced to $63 \%$, while that of $\mathrm{R} 2$ reduced from 85 to $61 \%$ within the same period. These changes are shown in Fig. 9a. This downward trend continued to $59 \%$ for both reactors until recovery. The effects clearly manifest in the physical appearance of the effluent with more TS concentration due to the low conversion of the substrate by the reactors. It is possible that the high VFA concentration might have prevented or reduced the mass transferability, in which some researchers [1, 9, 22, 32] have identified. Hence, the high viscosity of the effluent was presented. The same trend was observed with VS destruction efficiency (Fig. 9b), which reduced from $87 \%$ when oil was added to $60 \%$ for R1, and from 87 to $67 \%$ for R2. Strangely, these destruction efficiencies did not translate into biogas production. There is a need to investigate why a 60 and $67 \%$ destruction efficiency does not necessarily translate into biogas production because both reactors remained stagnated at $<3.7 \mathrm{~L}^{-1}$ day $^{-1}$ until recovery process took effects.

\section{Effects of $\mathrm{NaOH}$ Addition on the Reactors Recovery}

When the system failed the second time, plans were set in motion to recover them (R1 and R2) in stages. Firstly, a

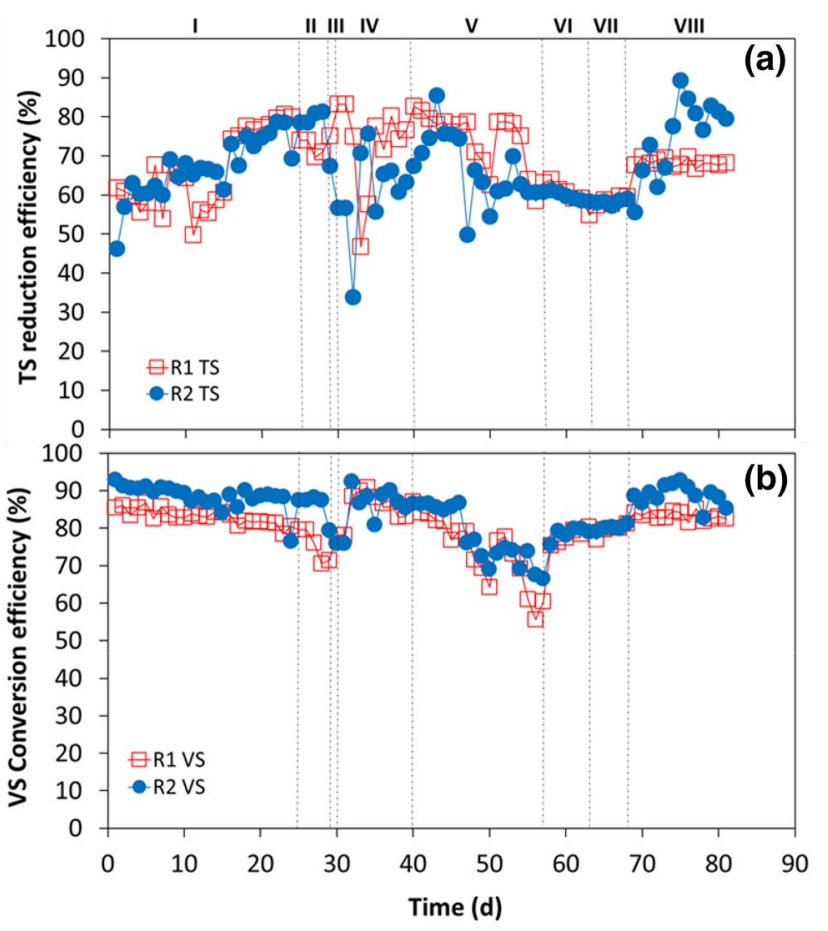

Fig. 9 Dynamic changes of a TS destruction efficiency, and b VS conversion efficiency, in the process of FW AD under mesophilic condition

standard solution of $3 \mathrm{~mol} \mathrm{~L}{ }^{-1} \mathrm{NaOH}$ was used to adjust the $\mathrm{pH}$ [11]. Titration method was employed in order to know the required quantity of $\mathrm{NaOH}$ to add to each reactor in order to increase the $\mathrm{pH}$. About $250 \mathrm{~mL}(2.5 \% \mathrm{v} / \mathrm{v})$ were added to the two reactors for the first 3 days during feeding, and later reduced to $50 \mathrm{~mL}(0.5 \% \mathrm{v} / \mathrm{v})$ for three additional days afterward and stopped when the $\mathrm{pH}$ was stable at $7.1 \pm 0.1$ for $\mathrm{R} 1$ and $7.2 \pm 0.1$ for $\mathrm{R} 2$, respectively (Fig. 8b). Apart from $\mathrm{pH}$ recovery, alkalinity has also increased due to the $\mathrm{NaOH}$ addition (for $\mathrm{R} 1$ from 200 to $5300 \mathrm{mg} \mathrm{CaCO}_{3} \mathrm{~L}^{-1}$ and for R2 from 300 to 4300 mg $\mathrm{CaCO}_{3} \mathrm{~L}^{-1}$ ), as shown in Fig. 7a. Even though TIC has already increased, it has no effect to buffer the high VFAs concentration probably due to low $\mathrm{pH}$ levels of both reactors. The question now is why VFAs was not reducing with the increased alkalinity, which plays a key role to buffer the acids and keep the reactor safe. This needs further investigation. However, the low mass transferability under high TS content and viscosity may have been a contributing factor to the continued increase in VFAs accumulation in this study. According to Hao et al. [9] and Wu et al. [52], the viscosity is a useful parameter for evaluation of the rheological characterisation which can influence $\mathrm{pH}$, temperature uniformity and the effectiveness of the microorganism during decomposition process in AD reactors. 


\section{Effect of Stopped Feeding on the Reactors Recovery}

The VFAs was on a steady increase as shown in Fig. 7b, thereby reducing the amount of biogas produced to $<3.7 \mathrm{~L}^{-1}$ day $^{-1}$. This may have been caused by the stressed microorganism not to consume the substrate supplied due to the high concentration of VFAs. Therefore, the second stage of the rescue was to stop feeding completely for at least 5 days, so that the methanogenic microorganisms can recover to consume and convert the accumulated VFAs in the reactors to biogas production. The effluent of the two reactors is a smooth-milky substance with little foams, with increased in viscosity especially for R2. This may have been caused by the dissolution of the accumulated LCFAs as a result of the addition of $\mathrm{NaOH}$ to the reactors, coupled with daily feeding that is not been utilised by the microorganisms. This had a significant effect on the effluent viscosity and increased TS concentrations as a result of the decreased mass transferability. This is in agreement with the previous investigation by Yu et al. [53], who reported that high TS concentration can severely reduce the mass and heat transfer among enzymes, bacteria, and substrates in the digesters. This situation was not helped as the two reactors were stirred intermittently by a top-mounted mechanical stirrer at $120 \mathrm{rpm}$ with $1 \mathrm{~h}$ 'on' and $1 \mathrm{~h}$ 'off', which in this case did not ensure total mixing. Adequate continuous mixing with slower rpm would have accelerated the diffusion processes, thereby improving the kinetics and helping in reducing the TS concentration and ultimately preventing high viscosity. This might be necessary at the first notice of high TS concentration from the effluent and changes in other parameters in future.

\section{Effect of Effluent Recirculation on the Reactors Recovery}

After observing the effects of $\mathrm{NaOH}$ addition without any recovery in biogas production, coupled with high VFA concentration, which continued to increase, $50 \%$ of the stored effluent was used by withdrawing the same amount from the reactor prior to the recirculation. This had an immediate effect on the biogas production and reduction in the VFA concentrations in both reactors. The characteristics of the effluent used in the recirculation and recovery are shown in Table 2, while the appreciable biogas recovery can be shown in Figs. 2 and 3. The effects on both VFA and alkalinity can be seen in Fig. 7. There was also an increase in TS reduction, VS, and TCOD conversion efficiency, as shown in
Figs. $9 \mathrm{a}, \mathrm{b}$ and $5 \mathrm{~b}$ respectively. The withdrawn effluent can be gradually mixed with the FW and added to the reactors without any inhibitions. It is important to note that this study is in the revision of the LCFAs inhibition, and high VFAs concentration was recirculated to degrade the LCFAs within a short lag phase. Also, the $50 \%$ recirculation of the active effluent increased the microbial/LCFAs ratio and resulted in the reactors' recovery.

\section{Conclusions}

The results showed that lipids inhibitions and other operational challenges of oil addition to FW could be addressed with the combination of $\mathrm{NaOH}$ addition coupled with recirculation of certain percentage of the digester's effluent, to kick-start dilution and breaking the LCFAs. The microorganisms were trapped by LCFA, thereby hindered the transfer process of methanogenic activities. This process has been proved to be reversible. There was a gradual reduction in the concentration of VFA from $6838 \mathrm{mg} \mathrm{L}^{-1}$ before recirculation to $2854 \mathrm{mg} \mathrm{L}^{-1}, 7$ days after recirculation, and for a quick resumption of biogas production. The biogas and production increased from $<3 \mathrm{~L}^{-1}$ day $^{-1}$ before recirculation to $13 \mathrm{~L}^{-1}$ $\mathrm{day}^{-1}$ for $\mathrm{R} 1$ and from $<3$ to $25 \mathrm{~L}^{-1} \mathrm{day}^{-1}$ for $\mathrm{R} 2$, while the methane production increased for $\mathrm{R} 1$, from $0.77 \mathrm{~L}^{-1}$ day $^{-1}$ before recirculation to $5.94 \mathrm{~L}^{-1}$ day $^{-1}$, and from 1.04 to $13.24 \mathrm{~L}^{-1} \mathrm{day}^{-1}$ for $\mathrm{R} 2$. This study provided an understanding of the dynamic complex nature of Chinese FW, especially because of its high salinity and lipids contents. In this study, ammonia was not a key inhibiting factor of FW in $\mathrm{AD}$, with a stable concentration of $1200 \mathrm{mg} \mathrm{L}^{-1}$ throughout the period, far less than the critical concentration of $3000 \mathrm{mg}$ $\mathrm{L}^{-1}$. Despite these positive results, there are potential questions that need to be answered, especially, on the role of free ammonia or ammonium on process performance and stability of AD, when there is high VFA concentration in the digester. Also, there is a need to investigate why a 60 and $67 \%$ destruction efficiency does not necessarily translate into biogas production because both reactors remained stagnated at $<3.7 \mathrm{~L}^{-1} \mathrm{day}^{-1}$ until recovery process took effects. Finally, changes in feeding patterns through gradual addition of lipid-rich waste (oil) to FW are suggested. This will allow slow adaptation by the microbial communities responsible for organic matter degradations.

Table 2 Analysis and characterisation of the buffer tank effluent used to reactivate the two reactors

\begin{tabular}{|c|c|c|c|c|c|c|c|c|c|}
\hline Parameter & TS (\%) & VS (\%) & VS/TS (\%) & $\operatorname{SCOD}\left(\mathrm{mg} \mathrm{L}^{-1}\right)$ & $\operatorname{TCOD}\left(\mathrm{mg} \mathrm{L}^{-1}\right)$ & $\begin{array}{l}\mathrm{NH}_{4}{ }^{+}-\mathrm{N}(\mathrm{mg} \\
\left.\mathrm{L}^{-1}\right)\end{array}$ & $\begin{array}{l}\mathrm{TIC}\left(\mathrm{mg} \mathrm{CaCO}_{3}\right. \\
\left.\mathrm{L}^{-1}\right)\end{array}$ & TVFA $\left(\mathrm{mg} \mathrm{L}^{-1}\right)$ & FOS/TAC \\
\hline Inoculum & 4.64 & 3.04 & 65.56 & 7000 & 38,750 & 2107 & 4300 & 364 & 0.08 \\
\hline
\end{tabular}


Acknowledgements The first author acknowledges the support from School of Civil Engineering, University College Dublin; Tuition scholarship support from Student Universal Support Ireland (SUSI); Centre RAPSODEE, Campus Jarlard, Albi, F-81013 Cedex 09, France and China Agricultural University, Key Laboratory of Clean Utilization Technology for Renewable Energy, Ministry of Agriculture. The author gratefully acknowledges colleagues and supervisor's contributions.

\section{References}

1. Zhang, W., Lang, Q., Fang, M., Li, X., Bah, H., Dong, H., Dong, R.: Combined effect of crude fat content and initial substrate concentration on batch anaerobic digestion characteristics of food waste. Bioresour. Technol. 232, 304-312 (2017). https://doi. org/10.1016/j.biortech.2017.02.039

2. Chen, X., Romano, R.T., Zhang, R.: Anaerobic digestion of food wastes for biogas production. Int. J. Agric. Biol. Eng. 3, 61-72 (2010)

3. Sun, Y., Wang, D., Yan, J., Qiao, W., Wang, W., Zhu, T.: Effects of lipid concentration on anaerobic co-digestion of municipal biomass wastes. Waste Manag. 34, 1025-1034 (2014). https://doi. org/10.1016/j.wasman.2013.07.018

4. Gamble, P.F., Zhang, R., El-mashad, H.M., Hartman, K., Wang, F.: Research Into Design and Modeling of Anaerobic Digestion Process Applied to Municipal Solid Wastes. (2015). https://doi. org/10.1016/j.biortech.2006.02.039

5. Meng, Y., Li, S., Yuan, H., Zou, D., Liu, Y., Zhu, B., Chufo, A., Jaffar, M., Li, X.: Evaluating biomethane production from anaerobic mono- and co-digestion of food waste and floatable oil (FO) skimmed from food waste. Bioresour. Technol. 185, 7-13 (2015). https://doi.org/10.1016/j.biortech.2015.02.036

6. Wang, H., Fotidis, I.A., Angelidaki, I.: Ammonia effect on hydrogenotrophic methanogens and syntrophic acetate-oxidizing bacteria. FEMS Microbiol. Ecol. (2015). https://doi.org/10.1093/ femsec/fiv130

7. Gunders, D.: Wasted: how America is losing up to 40 percent of its food from farm to fork to landfill. NRDC Issue Pap. 1-26 (2012).

8. Epa: Inventory of U.S. Greenhouse Gas Emissions and Sinks: 1990-2010. Www.Epa.Gov. 1-481 (2012).

9. Sun, H., Wu, S., Dong, R.: Monitoring volatile fatty acids and carbonate alkalinity in anaerobic digestion: titration methodologies. Chem. Eng. Technol. 39, 599-610 (2016). https://doi.org/10.1002/ ceat. 201500293

10. Lin, C.S.K., Pfaltzgraff, L.A., Herrero-Davila, L., Mubofu, E.B., Abderrahim, S., Clark, J.H., Koutinas, A.A., Kopsahelis, N., Stamatelatou, K., Dickson, F., Thankappan, S., Mohamed, Z., Brocklesby, R., Luque, R.: Food waste as a valuable resource for the production of chemicals, materials and fuels. Current situation and global perspective. Energy Environ. Sci. 6, 426 (2013). https://doi.org/10.1039/c2ee23440h

11. Zhang, T., Mao, C., Zhai, N., Wang, X., Yang, G.: Influence of initial $\mathrm{pH}$ on thermophilic anaerobic co-digestion of swine manure and maize stalk. Waste Manag. 35, 119-126 (2015). https://doi. org/10.1016/j.wasman.2014.09.004

12. Chen, Y., Cheng, J.J., Creamer, K.S.: Inhibition of anaerobic digestion process: a review. Bioresour. Technol. 99, 4044-4064 (2008). https://doi.org/10.1016/j.biortech.2007.01.057

13. Cho, H.S., Moon, H.S., Lim, J.Y., Kim, J.Y.: Effect of long chain fatty acids removal as a pretreatment on the anaerobic digestion of food waste. J. Mater. Cycles Waste Manag. 15, 82-89 (2013). https://doi.org/10.1007/s10163-012-0092-7

14. Wang, B., Nges, I.A., Nistor, M., Liu, J.: Determination of methane yield of cellulose using different experimental setups. Water
Sci. Technol. 70, 599-604 (2014). https://doi.org/10.2166/ wst. 2014.275

15. Fotidis, I.A., Karakashev, D., Kotsopoulos, T.A., Martzopoulos, G.G., Angelidaki, I.: Effect of ammonium and acetate on methanogenic pathway and methanogenic community composition. FEMS Microbiol. Ecol. (2013). https://doi. org/10.1111/j.1574-6941.2012.01456.x

16. Moestedt, J., Müller, B., Westerholm, M., Schnürer, A.: Ammonia threshold for inhibition of anaerobic digestion of thin stillage and the importance of organic loading rate. Microb. Biotechnol. (2016). https://doi.org/10.1111/1751-7915.12330

17. Rajagopal, R., Massé, D.I., Singh, G.: A critical review on inhibition of anaerobic digestion process by excess ammonia. Bioresour. Technol. 143, 632-641 (2013)

18. Alves, M., Vieira, M., Álvares, J., Pereira, R., Pereira, M., Mota, M.: Effects of lipids and oleic acid on biomass development in anaerobic fixed-bed reactors. Part II: oleic acid toxicity and biodegradability. Water Res. 35, 264-270 (2001). https://doi. org/10.1016/S0043-1354(00)00242-6

19. Astals, S., Batstone, D.J., Mata-Alvarez, J., Jensen, P.D.: Identification of synergistic impacts during anaerobic co-digestion of organic wastes. Bioresour. Technol. 169, 421-427 (2014). https://doi.org/10.1016/j.biortech.2014.07.024

20. Pastor, L., Ruiz, L., Pascual, A., Ruiz, B.: Co-digestion of used oils and urban landfill leachates with sewage sludge and the effect on the biogas production. Appl. Energy 107, 438-445 (2013). https://doi.org/10.1016/j.apenergy.2013.02.055

21. Alves, M.M., Pereira, M.A., Sousa, D.Z., Cavaleiro, A.J., Picavet, M., Smidt, H., Stams, A.J.M.: Waste lipids to energy: how to optimize methane production from long-chain fatty acids (LCFA). Microb. Biotechnol. 2, 538-550 (2009). https://doi. org/10.1111/j.1751-7915.2009.00100.x

22. Rasit, N., Idris, A., Harun, R., Wan Ab Karim Ghani, W.A.: Effects of lipid inhibition on biogas production of anaerobic digestion from oily effluents and sludges: an overview. Renew. Sustain. Energy Rev. 45, 351-358 (2015). https://doi. org/10.1016/j.rser.2015.01.066

23. Davidsson, $\AA$, Lövstedt, C., la Cour Jansen, J., Gruvberger, C., Aspegren, H.: Co-digestion of grease trap sludge and sewage sludge. Waste Manag. 28, 986-992 (2008). https://doi. org/10.1016/j.wasman.2007.03.024

24. Kim, J., Kang, C.-M.: Increased anaerobic production of methane by co-digestion of sludge with microalgal biomass and food waste leachate. Bioresour. Technol. 189, 409-412 (2015). https://doi.org/10.1016/j.biortech.2015.04.028

25. Kafle, G.K., Kim, S.H., Shin, B.S.: Anaerobic digestion treatment for the mixture of Chinese cabbage waste juice and swine manure. J. Biosyst. Eng. 37, 58-64 (2012)

26. Luo, G., Angelidaki, I.: Co-digestion of manure and whey for in situ biogas upgrading by the addition of $\mathrm{H} 2$ : process performance and microbial insights. Appl. Microbiol. Biotechnol. 97, 1373-1381 (2012). https://doi.org/10.1007/s00253-012-4547-5

27. Cirne, D.G., Paloumet, X., Björnsson, L., Alves, M.M., Mattiasson, B.: Anaerobic digestion of lipid-rich waste-effects of lipid concentration. Renew. Energy 32, 965-975 (2007). https:// doi.org/10.1016/j.renene.2006.04.003

28. Kim, M., Ahn, Y.H., Speece, R.E.: Comparative process stability and efficiency of anaerobic digestion; mesophilic vs. thermophilic. Water Res. (2002). https://doi.org/10.1016/ S0043-1354(02)00147-1

29. Mata-Alvarez, J., Dosta, J., Romero-Güiza, M.S., Fonoll, X., Peces, M., Astals, S.: A critical review on anaerobic co-digestion achievements between 2010 and 2013. Renew. Sustain. Energy Rev. 36, 412-427 (2014). https://doi.org/10.1016/j. rser.2014.04.039 
30. Long, J.H., Aziz, T.N., Reyes, F.L.D.L., Ducoste, J.J.: Anaerobic co-digestion of fat, oil, and grease (FOG): a review of gas production and process limitations. Process Saf. Environ. Prot. 90, 231-245 (2012). https://doi.org/10.1016/j.psep.2011.10.001

31. Alanya, S., Yilmazel, Y.D., Park, C., Willis, J.L., Keaney, J., Kohl, P.M., Hunt, J.A., Duran, M.: Anaerobic co-digestion of sewage sludge and primary clarifier skimmings for increased biogas production. Water Sci. Technol. 67, 174-179 (2013). https://doi. org/10.2166/wst.2012.550

32. Nghiem, L.D., Koch, K., Bolzonella, D., Drewes, J.E.: Full scale co-digestion of wastewater sludge and food waste: bottlenecks and possibilities. Renew. Sustain. Energy Rev. 72, 354-362 (2017). https://doi.org/10.1016/j.rser.2017.01.062

33. Palatsi, J., Viñas, M., Guivernau, M., Fernandez, B., Flotats, X.: Anaerobic digestion of slaughterhouse waste: main process limitations and microbial community interactions. Bioresour. Technol. 102, 2219-2227 (2011). https://doi.org/10.1016/j. biortech.2010.09.121

34. Hendriksen, H.V., Ahring, B.K.: Effects of ammonia on growth and morphology of thermophilic hydrogen-oxidizing methanogenic bacteria. FEMS Microb Ecol. (1991). https://doi. org/10.1111/j.1574-6968.1991.tb04730.x

35. Nielsen, H.B., Uellendahl, H., Ahring, B.K.: Regulation and optimization of the biogas process: propionate as a key parameter. Biomass Bioenergy (2007). https://doi.org/10.1016/j. biombioe. 2007.04.004

36. Alibardi, L., Cossu, R.: Composition variability of the organic fraction of municipal solid waste and effects on hydrogen and methane production potentials. Waste Manag. 36, 147-155 (2015). https://doi.org/10.1016/j.wasman.2014.11.019

37. Alibardi, L., Cossu, R.: Effects of carbohydrate, protein and lipid content of organic waste on hydrogen production and fermentation products. Waste Manag. 47, 69-77 (2016). https://doi. org/10.1016/j.wasman.2015.07.049

38. Algapani, D.E., Qiao, W., Su, M., Wandera, S.M., Adani, F.: Bioresource Technology Bio-hydrolysis and bio-hydrogen production from food waste by thermophilic and hyperthermophilic anaerobic process. Bioresour. Technol. 216, 768-777 (2016). https://doi.org/10.1016/j.biortech.2016.06.016

39. Cavinato, C., Bolzonella, D., Pavan, P., Fatone, F., Cecchi, F.: Mesophilic and thermophilic anaerobic co-digestion of waste activated sludge and source sorted biowaste in pilot- and fullscale reactors. Renew. Energy 55, 260-265 (2013). https://doi. org/10.1016/j.renene.2012.12.044

40. Nielsen, H.B., Mladenovska, Z., Westermann, P., Ahring, B.K.: Comparison of two-stage thermophilic (55 degree) anaerobic digestion with one-stage thermophilic (55 degree) digestion of cattle manure. Biotechnol Bioeng. (2004). https://doi.org/10.1002/ bit. 20037

41. APHA: Standard Methods for the Examination of Water and Wastewater. Public Health Association Ic, Washington DC (2005)
42. Nordmann, W.: Die Überwachung der Schlammfaulung. KAInformationen für das Betriebspersonal, Beilage zur Korrespondenz Abwasser. 3, 77 (1977)

43. Raposo, F., Rubia, M.A.D., Fernandez-Cegri, V., Borja, R.: Anaerobic digestion of solid organic substrates in batch mode: an overview relating to methane yields and experimental procedures. Renew. Sustain. Energy Rev. (2011). https://doi.org/10.1016/j. rser.2011.09.008

44. Borja, R., Rincón, B., Raposo, F., Domínguez, J.R., Millán, F., Martín, A.: Mesophilic anaerobic digestion in a fluidised-bed reactor of wastewater from the production of protein isolates from chickpea flour. Process Biochem. 39, 1913-1921 (2004). https:// doi.org/10.1016/j.procbio.2003.09.022

45. Lossie, U., Pütz, P.: Targeted control of biogas plants with the help of FOS / TAC. Pract. Rep. Hach-Lange. (2008)

46. Ferguson, R.M., Coulon, F., Villa, R.: Organic loading rate: a promising microbial management tool in anaerobic digestion. Water Res. 100, 348-356 (2016). https://doi.org/10.1016/J. WATRES.2016.05.009

47. Yi, J., Dong, B., Jin, J., Dai, X.: Effect of increasing total solids contents on anaerobic digestion of food waste under mesophilic conditions: performance and microbial characteristics analysis. PLoS ONE (2014). https://doi.org/10.1371/journal.pone.0102548

48. Wang, B., Strömberg, S., Li, C., Nges, I.A., Nistor, M., Deng, L., Liu, J.: Effects of substrate concentration on methane potential and degradation kinetics in batch anaerobic digestion. Bioresour. Technol. 194, 240-246 (2015). https://doi.org/10.1016/j. biortech.2015.07.034

49. Angelidaki, I., Ahring, B.K.: Effects of free long-chain fatty acids on thermophilic anaerobic digestion. Appl. Microbiol. Biotechnol. 37, 808-812 (1992). https://doi.org/10.1007/BF00174850

50. Banks, C.J., Zhang, Y., Jiang, Y., Heaven, S.: Trace element requirements for stable food waste digestion at elevated ammonia concentrations. Bioresour. Technol. 104, 127-135 (2012). https:// doi.org/10.1016/j.biortech.2011.10.068

51. Banks, C.J., Chesshire, M., Heaven, S., Arnold, R.: Anaerobic digestion of source-segregated domestic food waste: performance assessment by mass and energy balance. Bioresour. Technol. 102, 612-620 (2011). https://doi.org/10.1016/j.biortech.2010.08.005

52. Wu, S., Ni, P., Li, J., Sun, H., Wang, Y., Luo, H., Dach, J., Dong, R.: Integrated approach to sustain biogas production in anaerobic digestion of chicken manure under recycled utilization of liquid digestate: dynamics of ammonium accumulation and mitigation control. Bioresour. Technol. 205, 75-81 (2016). https://doi. org/10.1016/j.biortech.2016.01.021

53. Yu, L., Ma, J., Chen, S.: Numerical simulation of mechanical mixing in high solid anaerobic digester. Bioresour. Technol. 102, 1012-1018 (2011). https://doi.org/10.1016/J. BIORTECH.2010.09.079 